\title{
Rapid Detection of Toxic Dinoflagellate, Alexandrium minutum (Dinophyceae) Using Fluorescence In Situ Hybridization (FISH)
}

\author{
Leh-Hie Yek ${ }^{1}$, Kieng-Soon Hii ${ }^{1}$, Toh-Hii Tan ${ }^{1}$, Nyuk-Fong Kon ${ }^{1}$, Po-Teen Lim², Chui-Pin Leaw ${ }^{1 *}$ \\ ${ }^{1}$ Institute Biodiversity and Environmental Conservation, Universiti Malaysia Sarawak, 94300 Kota Samarahan, Sarawak, \\ Malaysia. \\ ${ }^{2}$ Faculty of Resource Science and Technology, Universiti Malaysia Sarawak, 94300 Kota Samarahan, Sarawak, Malaysia. \\ *cpleaw@ibec.unimas.my, chuipinleaw@gmail.com (Corresponding Author)
}

\begin{abstract}
Harmful algal blooms (HABs) are phenomena known as sudden increase in Microalgal population that cause seafood poisoning in human and impact to marine ecosystem. Dinoflagellates from the genus Alexandrium had been known to be responsible for paralytic shellfish poisoning (PSP) toxins with the production of sodium blocking neurotoxins collectively called saxitoxin (STX). Species identification in thisgenus is based on thecal plate tabulation and minute morphological character, which is often hard to observe during regular plankton monitoring that require taxonomic expertise. Hence, a molecular detection approach using whole-cell fluorescence in situ hybridization (FISH) was investigated in this study for the rapid detection of Alexandrium. Ribosomal DNA probes targeting the toxic A.minutum were designed in silico. Specificity and accessibility of designed probes were further verified in silico by comparing parameters that influenced hybridization kinetics. Species-specific probe which was designated as L-S-Amin-569-A-18 was synthesized and optimized using the clonal cultures of A. minutum. The results showed that the DNA probe had high specificity towards A. minutum, with no cross-reactivity towards other Alexandrium species. The whole-cell FISH coupled with the speciesspecific probe showed its potency as a rapid detection tool of A. minutum in Malaysian waters, which could be adopted in the national harmful algal monitoring program.
\end{abstract}

(Keywords: Paralytic shellfish poisoning (PSP); Alexandrium minutum, "fluorescence in situ hybridization" (FISH);DNA probe)

\section{INTRODUCTION}

Paralytic shellfish poisoning (PSP) is a type of seafood poisoning due to consumption of shellfish molluscs contaminated by neurotoxins, saxitoxin (STX). The toxins blocked sodium channels in mammalian nerve cells and thus prevent signal propagation along the neuron $[1,2]$. Monitoring program on plankton and shellfish toxicity has been implemented in most countries affected by PSP as proactive measures in seafood safety. Early detection and enumeration of harmful algal species is pivotal in preventing human intoxication and impacts on ecological and economic aspects [2].

Worldwide distribution of toxic species in the genus Alexandrium has increased the severity of PSP. Cooccurrence of toxic Alexandrium species with non-toxic but morphologically highly similar further complicated the effort in plankton monitoring. In Malaysian waters, A. minutum and A. tamiyavanichii are responsible for PSP events in the Peninsular Malaysia [3, 4, 5, 6]. These species have been found as part of the phytoplankton assemblages with non-toxic $A$. leei and A. affine $[3,7]$ and low toxic $A$. tamarense[8].

Saxitoxins are tasteless, odorless, and toxicity remained stable after cooking processes. Therefore, a variety of detection techniques using molecular approaches such as fluorescence in situ hybridization (FISH) [9, 10], DNA microarrays, real-time quantitative PCR [11], and sandwich hybridization assays (SHAs) [12] have been employed for the rapid detection of harmful algal species [13].

Monitoring of toxic algae using morphological identification and conventional microscopic procedures is time consuming, and requires taxonomic expertise. Alexandrium minutum is difficult to differentiate among species as it was only characterized by minute morphological details in the thecal plates. Hence, FISH with chemiluminescent detection is a more suitable tool for rapid and reliable detection of harmful algae [10, 
14, 15]. Moreover, this method requires a considerable shorter time compared to other methods.

In this study, species-specific oligonucleotide probe was designed in silico in large subunit ribosomal RNA using the ARB package. The designed probes were subsequently evaluated based on factors that influenced hybridization kinetics and efficiency. The optimum probe was then tested and applied on cultured Alexandrium species. Targeted cell were detected with the assistance of light and epi-fluorescence microscope equipped with a charge coupled device (CCD) camera. Probe optimization such as probe stability, probe intensity and cross reactivity of the probe was undertaken in order to validate the efficiency of probe.

\section{MATERIALS AND METHODS}

\section{Algal cultures}

Clonal cultures of Alexandrium minutum and several other Alexandrium species were grown in ES-DK medium [16] at $25 \pm 0.5^{\circ} \mathrm{C}$ under condition of $12: 12 \mathrm{~h}$ light : dark cycle, with photon flux of $140 \mu$ mol photon $\mathrm{m}^{-2} \mathrm{~s}^{-1}$. Filtered natural seawater diluted to $15 \mathrm{psu}$ was used as medium basefor $A$. minutum cultures, while for other Alexandrium species salinity of $30 \mathrm{psu}$ was used. The medium $\mathrm{pH}$ was adjusted to $7.8-7.9$ by adding $10 \% \mathrm{HCl}$.

\section{Morphological observation}

All clonal cultures of Alexandrium species used in this study were confirmed based on morphological features such as shape of apical pore plate, presence of ventral pore on 1' apical plate and also the position of posterior and attachment pores as previously described $[5,6,7$, $17,18]$. Cells were fixed with $4 \%$ paraformaldehyde for not more than an hour,subsequently stained with $1 \%$ calcofluor white (Sigma) solution for $10 \mathrm{~min}$, and finally viewed under an Olympus IX51 research microscope (Olympus, Tokyo, Japan) equipped with UV filter sets. Stained cells were analyzed and images were captured with the CCD camera.

\section{Phylogenetic reconstruction}

Nucleotide sequences of the large subunit (LSU) ribosomal RNA gene of the species used in this study were retrieved from Genbank nucleotide database (NCBI). The LSU rDNA were initially aligned using Clustal X[19], and the alignment were further edited manually using BioEdit ver 7.0[20]. Phylogenetic analyses were performed using PAUP* ver. 4.0b10 [21].

\section{In silico rRNA-targeted oligonucleotide probes design}

The rRNA-targeted oligonucleotide probes were designed in silico using PROBE Design Tool (PDT) of the ARB software package [22]. PDT searched the entire possible target sites and also probe sequences that are diagnostic for the selected species. Some parameters like hybridization efficiency assisted in selecting the most suitable probe sequence. The selected probe was compared against the whole database by using PROBE Match tool (PMT) of ARB software package. For confirmation, the unambiguous sequences were then blasted in BLAST search (Genbank, NCBI) [23] to check against all currently available sequences.

\section{Nomenclature of probe}

In this study, the selected probe was chosen for probe synthesis for use in whole-cell FISH. The nomenclature of probe was adopted from[24]. The selected probe was designated as L-S-Amin-569-A-18.

\section{Whole-cell fluorescence in situ hybridization (FISH) optimization}

Before performing the whole-cell FISH protocol, cells were counted using a Sedgewick-Rafter slide under a light microscope as to determine the suitable volume of cell suspension required for harvesting as well as microscopic detection. One milliliter subsamples were taken for triplicate counts.

Cells in the exponential phase were harvested by centrifugation $(2000 \times g, 5 \mathrm{~min})$ and fixed with $4 \%$ paraformaldehyde at $4^{\circ} \mathrm{C}$ for $1 \mathrm{~h}$. Cell pellets were dehydrated with an ethanol series ( $70 \%$ for $5 \mathrm{~min}, 90 \%$ for $5 \mathrm{~min}$ ) at room temperature.Cells were spun down and pellets were rinsed with $1 \mathrm{~mL}$ of $10 \times$ PBS for $5 \mathrm{~min}$ (1-2 times) to remove excess ethanol, and followed by $1 \mathrm{~mL} 25 \times$ hybridization buffer $(3.75 \mathrm{M} \mathrm{NaCl}, 25 \mathrm{mM}$ EDTA, $0.5 \mathrm{M}$ TrisHCl, pH 7.8). The samples were then spun down again and supernatant discarded.

Cell pellet was resuspended in $200 \mu \mathrm{L}$ pre-warmed hybridization buffer [ $5 \times$ SET, $0.1 \%(\mathrm{v} / \mathrm{v})$ Nonidet P-40]containing $0.5 \mathrm{ng} \mu \mathrm{L}^{-1}$ of probes (species-specific probe, Universal eukaryotic probe, uniC and negative control probe, uniR). Mixtures were incubated for $45 \mathrm{~min}$ at $55^{\circ} \mathrm{C}$. Subsequently hybridized samples 
were centrifuged and supernatant with excess probe discarded. Cell pellets were rinsed with $1 \mathrm{~mL}$ prewarmed $5 \times$ SET for 5 min to stop the hybridization reaction. Samples were spun again and cell pellet were resuspended in $200 \mu \mathrm{L} 5 \times \mathrm{SET}$.

Total of $10 \mu \mathrm{L}$ of each sample was transferred onto a microscope slide. Approximately $20 \mu \mathrm{L}$ of Slow Fade Light (Invitrogen, CA, USA) was added to each sample. The slide was covered with a cover slip and observed under an Olympus IX51 epi-fluorescence inverted microscope (Olympus, Tokyo, Japan) equipped with UV filter sets. Fluorescent images were captured through CCD camera for image analysis.

\section{RESULTS}

\section{Morphological observation of cultured Alexandrium species}

All clonal cultures of Alexandrium species used in this study were confirmed based on the thecal morphology; they are A. minutum (AmKB06), A. tamiyavanichii (AcSm01), A. affine (AaSm01), and A. tamutum (AuKA01). Thecal plate tabulation of Alexandrium is Po, 4', 6", 5"', 2"', 6c and 9-10s according to Kofoidian plate formula [17].Epi-fluorescence micrographs of $A$. minutum showed the narrow and long sixth precingular plate (6"), and a typical minutum-type anterior sulcal plate (s.a.) which is slight wavy in appearance (Figure 1A, B).

\section{LSU rDNAphylogeny of Alexandrium}

The multiple alignments of 29 nucleotide sequences of LSU rDN Ayielded 552 characters. Phylogenetic analyses (Maximum Parsimony, MP; Maximum Likelihood, ML; Bayensian Inference, BI) yielded identical tree topologies, with ML tree shown here(Figure 2). The topologies resolved two monophyletic clades, namely Clade 1 and Clade 2, respectively. Alexandrium minutum is closely related to $A$. lusitanicum, A. insuetum, A. tamutum, and $A$. ostenfeldii, forming a monophyletic group as Clade 1 . On the other hands, A. tamerense, $A$. catenella, A. affine, A. tamiyavanichii and A. fraterculus formed another clade which is far more distant than $A$. minutum.

\section{Phylogeography of A. minutum}

The A. minutum group were further analysed phylogenetically based on the geographical origin.
In this analysis, taxon sampling was restricted to A. minutum from different geographical origins. Total of 30 sequences were retrieved from the NCBI nucleotide database, with an alignment yielding 571 characters(including gaps). Two monophyletic clades of A. minutum were resolved in all the phylogenetic analyses (MP, ML, and BI) (Figure 3). Alexandrium minutum from Malaysia that used in this study has close relationship with $A$. minutum from China, Taiwan, New Zealand and USA. However, A. minutum from Italy, France, Spain, England or Ireland were split out as Clade 2.

\section{in silico rRNA oligonucleotide evaluation and probe design}

For in silicoprobe design, the target species $A$. minutumspecies were retrieved from SILVA database. A total of 334 Alexandrium sequences were used. A total of 51 potential probe regions were selected in silico for A. minutum(Table 1). Four out of 51potential probes showed $100 \%$ hybridization efficiency (HE), with Gibb's free energy values $\left(\Delta \mathrm{G}^{\mathrm{o}}{ }_{\text {overall }}\right)$ less than the threshold $-13 \mathrm{kcal} / \mathrm{mol}$.

Parameters that influenced hybridization kinetics and stability of probe such as length of probe, melting temperature $\left(\mathrm{T}_{\mathrm{m}}\right), \mathrm{G}+\mathrm{C}$ contents are shown in Table 2. Three proposed probes (probe 2,3,4) are with lengths of 18 -mer, $\mathrm{T}_{\mathrm{m}}$ of $60^{\circ} \mathrm{C}$ and $\mathrm{G}+\mathrm{C}$ contents of $66.7 \%$. Probe 1 had slightly lower $\mathrm{G}+\mathrm{C}$ content $(61.1 \%)$ and lower $\mathrm{T}_{\mathrm{m}}$ compared to others.Confirmatory test was performed with Blastn via NCBI nucleotide database to detect the potential matching target sequences in species from nontarget and non-algal groups in the database. The results of the in silico search revealed an E-value of 1.0 which is considered as good probe specificity.

In this study, the selected probe region revealed high numbers of mismatches compared to other species of Alexandrium(Figure 4). The results showed probe 3 had the highest number of mismatches. Thus, the probe is selected for further probe synthesis and the probe was designated as L-S-Amin-569-A-18 according to Probe Nomenclature, with the sequence of 5 , AGUCCCUUCCCCGUUGGC 3'.

\section{Mismatch analysis of $A$. minutumspecies-specific probe}

The separation of two geographical groups of A. minutum based on our phylogenetic analyses in Figure 3 and others (e.g. $[6,25])$ revealed a high genetic divergence 
in A. minutum. In this study, a species-specific probe was designed to detect the populations that encountered in our waters. Thus, potential probe region targeting species in Malaysia and Taiwan (Clade 1) was chosen.

Mismatch analysis of the probe against all available Alexandrium sequences in the public databases (SILVA and GenBank) showed that no mismatch was found between the probe and the target $A$. minutum in the Pacific region (Clade 1). On the other hand, comparison of the probe regions against $A$. minutum of non-Pacific region(Clade 2) recovered as many as seven mismatches (Table 3).

\section{Stringency analysis}

in silico analysis offormamide concentration showed no hybridization could occur between the probe and A. minutum from France, A. minutum in Clade 2 (nonPacific region). The results further indicated that the probe selected has high hybridization efficiency $(100 \%)$ and high specificity, thus this probe could be applied towards FISH without addition of formamide.

\section{Whole-cell fluorescence in situ hybridization(FISH)}

Whole-cell FISH with FITC-labeled rDNA probe was performed with clonal cultures of $A$. minutum,with $A$. tamiyavanichii (AcSm01) and A. tamutum (AuKA01) as the non-target species. The universal eukaryotic probe, Uni $\mathrm{C}$ was acted as a positive control probe and when hybridized with the probe, A. minutum, $A$. tamiyavanichii and A. tamutum cells all showed clear green fluorescent signal (Figure 5A).As a negative control, the probe UniR was applied to the experiment and the results showed no green fluorescent signal from A. minutum, A. tamiyavanichii and A. tamutum cells (Figure 5B). However, some weak yellowish signal was observed within the cells which may due to cell autofluorescence. On the other hand, the A. minutum species-specific probe [L-S-Amin-569-A-18] gave positive green fluorescent signal when hybridized with A. minutum (Figure 5C); the cell showed only green fluorescent at a specific region instead of whole-cell.

To confirm the specificity of the probe, cross-reactivity of the probe towards non-target species, A. tamiyavanichii and $A$. tamutum were tested. When the probe applied on A. tamiyavanichii and A. tamutum cells, the cells did not show any green fluruoscent (Figure 5D, 5E). The results clearly indicated that the probe is species-specific and thus confirmed the specificity of the probe designed.

\section{Optimization of FISH}

To optimize the condition of FISH, several parameters were optimized in this study to obtain the maximum efficiency of probe binding. These included hybridization temperature, time of fixation and chemical compounds used in hybridization, for instances formamide concentration, washing buffer concentration, probe concentration, fixative.

Good fixation of cells is pivotal in the initial procedure of whole-cell FISH. In this study, two common fixatives used in FISH were tested for their efficiency. Our results showed that paraformaldehyde (4\%) fixed the dinoflagellate cells better compared to the modified saline ethanol (data not shown). Optimum probe concentration was determined by varying the final concentration in hybridization. In this study, the concentration at $200 \mathrm{ng} \mu \mathrm{L}^{-1}$ was shown to have higher intensity compared to other diluted concentrations of probe. Optimum hybridization temperature used in this study ranged from $45^{\circ} \mathrm{C}$ to $58^{\circ} \mathrm{C}$. Cells hybridized at temperature of $55^{\circ} \mathrm{C}$ were selected due to higher probe specificity and intensity.

\section{DISCUSSION}

The LSU rDNA sequences of Alexandrium spp. indicated that the D1-D2 region could provide a species-specific genetic marker for the genus Alexandrium. Classification based on phylogenetic relationships within this genus based on the sequences retrieved from D1-D2 region rDNA is congruent with morphological taxonomy [6, $18,19,20,25]$, and thus could be used to assist in the probe design [26, 27]. DNA probe sequence selected must be specific to differentiate the target organisms not only from closely related species but also from a great number of other non-related organisms in the field [28].

In the present study, several common technical problems were observed in applying whole-cell FISH. We present here some solutions for the problems occurred. Under epi-fluorescence microscopy, small yellowish pyrenoidlike spots in the cells often appeared after UV excitation, and sometimes could be misleading as positive results of hybridization. This could be distinguished from the positive green fluorescence signal where the whole cells are often fluorescently stained.The identity of this fluorescent organelle is still unclear though[29]. The occurrence of auto-fluorescence in Alexandrium has caused masking of hybridization signals with FISH assays. However, auto-fluorescence of Alexandrium spp. could be greatly reduced by ethanol series after fixation. 
Paraformaldehyde has been widely used for fixation owing its easier cell wall permeabilization for binding of target molecules in cytosol and DNA probe molecules[28]. Of various fixation agents tested such as paraformaldehyde, glutaraldehyde and modified saline ethanol, paraformaldehyde was found to be the most suitable fixative for FISH (with a fixation time of not more than $1 \mathrm{~h}$ ). Glutaraldehyde (final concentration of $0.1 \%$ ) caused higher fluorescence background and also lower signal strength of cells compared to paraformaldehyde. Modified saline ethanol has been reported as effective at permeabilizing cell wall of microalgal species include diatom (especially Pseudo-nitzschia species) and also thecate or non-thecate dinoflagellates [30]. This solution allows strong cell permeablization and allows probe to access target molecules[31]. However, the fixative did not work well with Alexandrium spp. as strong autofluorescence was observed in this study.

To obtain the highest probe reactivity (fluorescence intensity) of labelled cells without background noises, optimum hybridization temperature and conditions were determined in this study. Hybridization depends on the ability of oligonucleotide to anneal to a complementary mRNA strand just below its melting point $\left(\mathrm{T}_{\mathrm{m}}\right)$ where half of the oligonucleotide presented in single-stranded condition. Application of FISH protocol using higher temperature has been considered as effective way to decrease the non-specific binding. This also increases the accessibility of targeted rRNA to oligonucleotide DNA probe.

In this study, FISH protocol was optimized at $55-58^{\circ} \mathrm{C}$, which was considered high as compared with the usual hybridization temperature $\left(45^{\circ} \mathrm{C}\right.$ or even lower). High temperatures lead to conformation of secondary and tertiary structure of rRNA as well as to ensure both oligonucleotide probe and targeted fragments of rRNAs strands allocate at correct orientation. Hybridization temperature was closely related to fluorescence intensity because temperature not only affected dissociation of probe but also affects conformation of targeted rRNA. Hybridization temperature that was significantly below the theoretical $\mathrm{T}_{\mathrm{m}}$ easily binds to non-targeted nucleic acid.

DNA targeted probe can be applied either as a wholecell FISH where the signal was found throughout the cytoplasm due to ribosomal distributions or the probe is merely hybridized to nuclear-encoded DNA that the signal were only observed from nuclei[32].
Applying DNA probe may be advantageous for quantifying cells compared to RNA probe. Probe hybridized with rRNA and rDNA differ in their perspectives. rRNA are highly abundance in cells but rRNA abundance varies among cells physiological condition and thus show varying intensity, leading to errors when quantification of target cells. Although rDNA is less abundance, the advantages of using rDNA is that the number of targeted cells will not vary depends on physiological or environmental conditions (except during cell divisions) and hence it can be used for quantification of target cells.

DNA probes have great potential as diagnostic tools because they are capable to distinguish strain-specific genotypes because genetic signatures should not be affected when cells experience changing environmental conditions[33]. DNA-targeted probe is hybridized to nucleus of the cells, showing that DNA probe has more specificity as compared to RNA probe. DNA probe had advantage compared to RNA probe in term of storage. DNA can be stored longer in low temperature compared to RNA probe which needs to be frozen in $-20^{\circ} \mathrm{C}$ since RNA is easier to degrade.

\section{CONCLUSION}

In silico probe design using ARB software was shown to be an advanced tool for probe design. Moreover, fluorescently labelled species-specific probe tested in this study showed high efficiency to rapidly detect cells of A. minutum, and did not show cross reactivity with other closely related species. Hence, the probe [L-S-Amin-569-A-18] shows great promise as a tool for rapid detection of A. minutum in Malaysia. In addition, optimization of the hybridization conditions has provided a better resolution of probe binding and efficiency.

\section{REFERENCES}

1. Schantz, E. J., Lynch, J. M., Vayvada, G., Matsumoto, K. and Rapoport, H. (1966). The purification and characterization of the poison produced by Gonyaulax catenella in axenic culture. Biochemistry5: 1191-1195.

2. Kao, C. Y. (1993). Paralytic shellfish poisoning. In Falconer, I. R. (Ed.) Algal Toxins in Seafood and Drinking Water. Academic Press: London, UK, pp 75-86. 
3. Usup, G., Leaw, C. P., Ahmad, A. and Lim, P. T. (2002). Alexandrium (Dinophyceae) species in Malaysian waters. Harmful Algae 1: 265-275.

4. Lim, P. T., Leaw, C. P. and Usup, G. (2004). First incident of paralytic shellfish poisoning on the east coast of Peninsular Malaysia. In Phang, S. M., Chong, V. C., Ho, S. S., Mokhtar, N. \&Ooi, J. L. S. (Eds.) Marine Science into the new Millenium: New Perspectives and Challenges. University of Malaya, Maritime Research Centre, Kuala Lumpur, Malaysia. pp 661-667.

5. Lim, P. T., Leaw, C. P. and Ogata, T. (2007). Morphological variation of two Alexandrium species responsible for paralytic shellfish poisoning in Southeast Asia. Botanica Marina 50: 14-21.

6. Leaw, C. P., Lim, P. T., Ng, B. K., Cheah, M. Y., Ahmad, A. and Usup, G. (2005). Phylogenetic analysis of Alexandrium species and Pyrodinium bahamense (Dinophyceae) baesd on theca morphology and nuclear ribosomal gene sequence. Phycologia 44: 550-565.

7. Lim, P. T., Leaw, C. P. andUsup, G. (2003). Identification of Alexandriumhalim (Dinophyceae) using EPI-fluorescence microscopy. Annals of Microscopy 3: 102-107.

8. Lim, P. T. and Ogata, T. (2005). Salinity effect on growth and toxin production of four tropical Alexandrium species (Dinophyceae). Toxicon 45: 699-710.

9. Simon, N., Campbell, L., Ornolfsdottir, E., Groben, R., Guillou, L., Lange, M. and Medlin, L. K. (2000). Oligonucleotide probes for the identification of three algal groups by dot blot and fluorescent whole-cell hybridization. The Journal of Eukaryotic Microbiology 47: 76-84.

10. Groben, R. and Medlin, L. (2005). in situ hybridization of phytoplankton using fluorescently labeled rRNA probes. Methods in Enzymology 395:299-310.

11. Galluzzi, L., Penna, A., Bertozzini, E., Vila, M., Garces, E. and Magnani, M. (2004). Development of a real-time PCR Assay for rapid detection and quantification of Alexandrium minutum (a dinoflagellate). Applied and Environment Microbiology 70: 1199-1206.

12. Scholin, C.A., Buck, K. R., Britschgi, T., Cangelosi, G. and Chavez, F. P. (1996). Identification of Pseudo-nitzschia australis (Bacillariophyceae) using rRNA-targeted probes in a whole-cell and sandwich hybridization format. Phycologia 35: 190-197.

13. Diercks, S., Metfiers, K. and Medlin, L. K. (2008). Molecular probe sets for the detection of toxic algae for use in sandwich hybridization formats. Journal of Plankton Research30: 439-448.

14. Anderson, D. M., Kulis, D. M., Keafer, B. A., Gribble, K. E., Marin, R. and Scholin, C. A. (2005). Identification and enumeration of Alexandrium spp. from the Gulf of Maine using molecular probes. Deep Sea Research Part II 52:2467-2490.

15. Hosoi-Tanabe, S. and Sako, Y. (2005). Rapid detection of natural cells of Alexandrium tamarense and A. catenella (Dinophyceae) by fluorescence in situ hybridization. Harmful Algae 4:319-328.

16. Kokinos, J. P. and Anderson, D. M. (1995). Mophological development of resting cycts in cultures of the marine dinoflagellate lingulodinium polyedrum (= l. machaerophorum). Palynology 19: 143-166.

17. Balech, E. (1995) The Genus Alexandrium Halim (Dinoflagellata). Sherkin Island Marine Station, Cork, Ireland, p. 151.

18. Hansen, G., Daugbjerg, N. and Franco, J. M. (2003). Morphology, toxin composition and LSU rRNA phylogeny of Alexandrium minutum (Dinophyceae) from Denmark, with some morphological observations on other European strains. Harmful Algae 2:317-335.

19. Thompson, J. D., Gibson, T. J., Plewniak, F., Jeanmougin, F. and Higgins, D. G. (1997). The Clustal X windows interface: flexible strategies for multiple sequence alignment aided by quality analysis tools. Nucleic Acid Research 25: 48764882.

20. Hall, T. A. (1999). Bioedit: a user-friendly biological sequence alignment editor and analysis program for Widows 95/98/NT. Nucleic acid Symposium Series 41: 95-98.

21. Swofford, D. L. (2000). PAUP*. Phylogenetic Analysis Using Parsimony (*and Other Methods). Version 4. Sinauer Associates, Sunderland, Massachusetts.

22. Ludwig, W., Strunk, O., Westram, R., Richter, L., Meier, H., Yadhukumar, Buchner, A., Lai, T., steppi, S., Jobb, G., Foster, W., Brettske, I., Gerber, S., Ginhart, A. W., Gross, O., Grumann, S., Hermann, S., Jost, R., Konig, A., Liss, T., Lubmann, R., May, M., Nonhoff, B., Reichel, B., Strehlow, R., Stamatakis, A., Stuckmann, N., Vilbig, A., Lenke, M., Ludwig, T., Bode, A. and Schleifer, K. (2004). ARB: A software environment for sequence data. Nucleic acids research 32: 1363-1371.

23. Altschul, S. F., Gish, W., Miller, W., Myers, E. W. \& Lipman D. J. (1990). Basic local alignment 
search tool. Journal Molecular Biology 215: 403-410.

24. Elizabeth, W. A., Daniel, B. O., Niels, L., David, S. A. and Lutgarde, R. (1996). The oligonucelotide probe database. Applied and Environmental Microbiology 62: 3557-3559.

25. Lily, E. L., Halanych, K. M. and Anderson, D. M. (2005). Phylogeny, biogeography, and species boundaries within the Alexandrium minutum group. Harmful Algae 4:1004-1020.

26. Scholin, C. A. Herzog, M., Sogin, M. and Anderson, D. M. (1994). Identification of groupand strain-specific genetic markers for globally distributed Alexandrium (Dinophyceae). II. Sequence analysis of a fragment of the LSU rRNA gene. Journal Phycology 30: 999-1011.

27. Scholin, C. A. and Anderson, D. M. (1996). Identification of Alexandrium species and strains using RELP analysis of PCR-amplified LSU rDNA. In Yasumoto, T., oshima, Y. \& Fukuyo, Y. (Eds.). Harmful and Toxins Algal Blooms. Intergovermental Oceanographic Commision of UNESCO , Paris, pp. 451-454.

28. Kim, C. J., Yoshimatsu, S., Sako, Y. and Kim, C. (2004). Journal Fish science Technology 7: 175-183
29. Kim, C. J. and Sako, Y. (2005). Molecular identification of toxic Alexandrium tamiyavanichii (Dinophyceae) using two DNA probes. Halmful Algae 4: 984-991

30. Miller, P. E. andScholin, C. A. (2000). On detection of Pseudo-nitzschia (Bacillariophyceae) species using whole cell hybridization: sample fixation and stability. Journal of Phycology 36: 238-250

31. Miller, P. E. andScholin, C. A. (1996). Identification of cultured Pseudo-nitzschia (Bacillariophyceae) using species-specific LSU rRNA-targeted fluorescent probes. Journal of Phycology 32: 645-55.

32. Sako,Y., Hosoi-Tanabe, S. and Uchida, A. (2004). Fluorescence in situ hybridization using rRNA probes for simple and rapid identification of the toxic dinoflagellates Alexandrium tamarense and Alexandrium catenella. Journal of Phycology 40: 598-605.

33. Adachi, M., Sako, Y.and Ishida, Y. (1996). Identification of the toxic dinoflagellates Alexandrium catenella and A. tamarense (Dinophyceae) using DNA probes and whole-cell hybridization. Journal of phycology. 32: 1049-53.

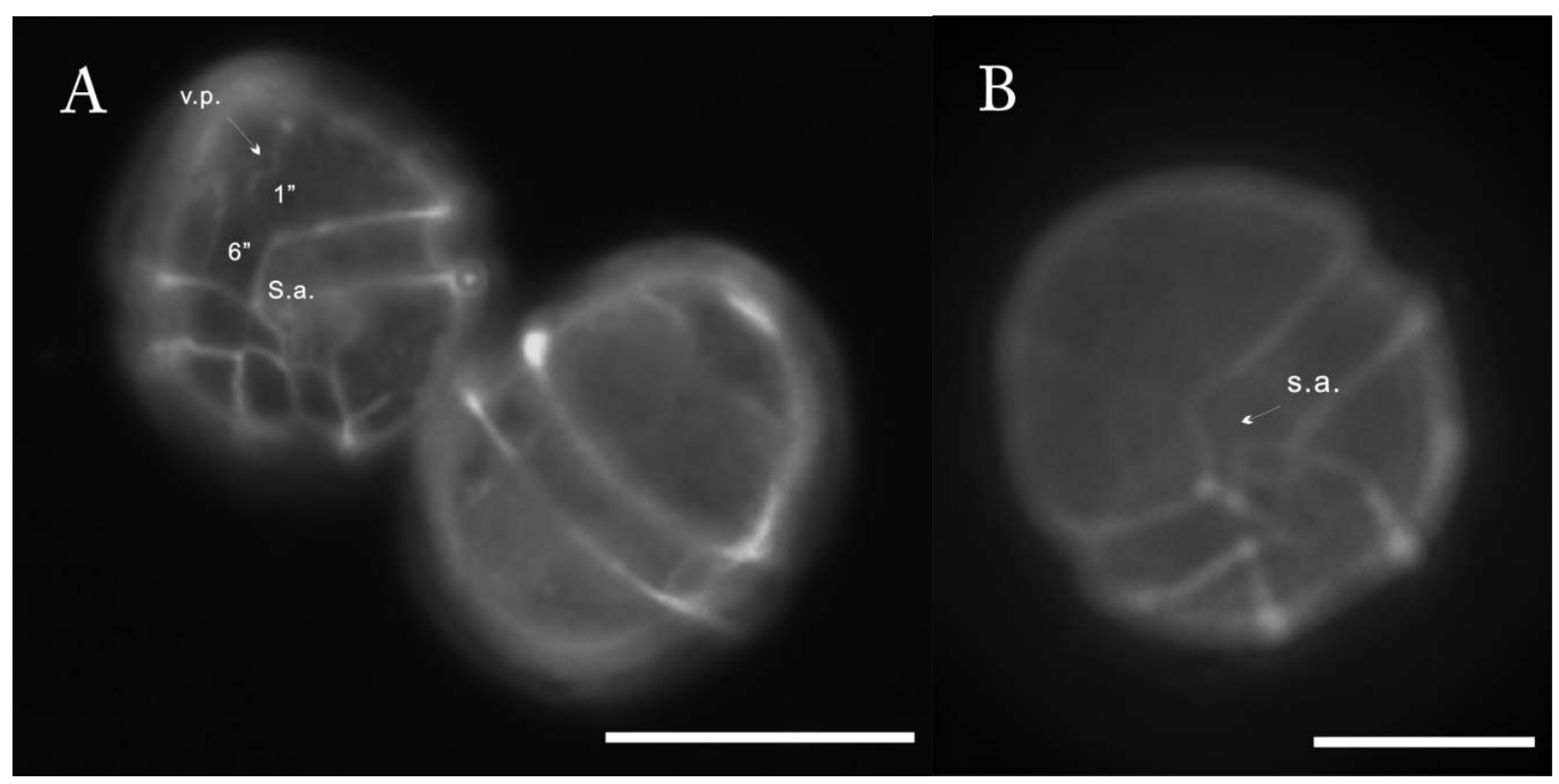

Figure 1. Epi-fluorescence micrographs of cells of $A$. minutum and did (A) Ventral view showing first apical plate $\left(1^{\prime}\right)$ with ventral pore (v.p.). The sixth precingular plate (6") is narrow and long. (B) Anterior sulcal plate (s.a.). Scale bars = $10 \mu \mathrm{m}$ 


\section{$\mathrm{MP} / \mathrm{ML} / \mathrm{BI}$}

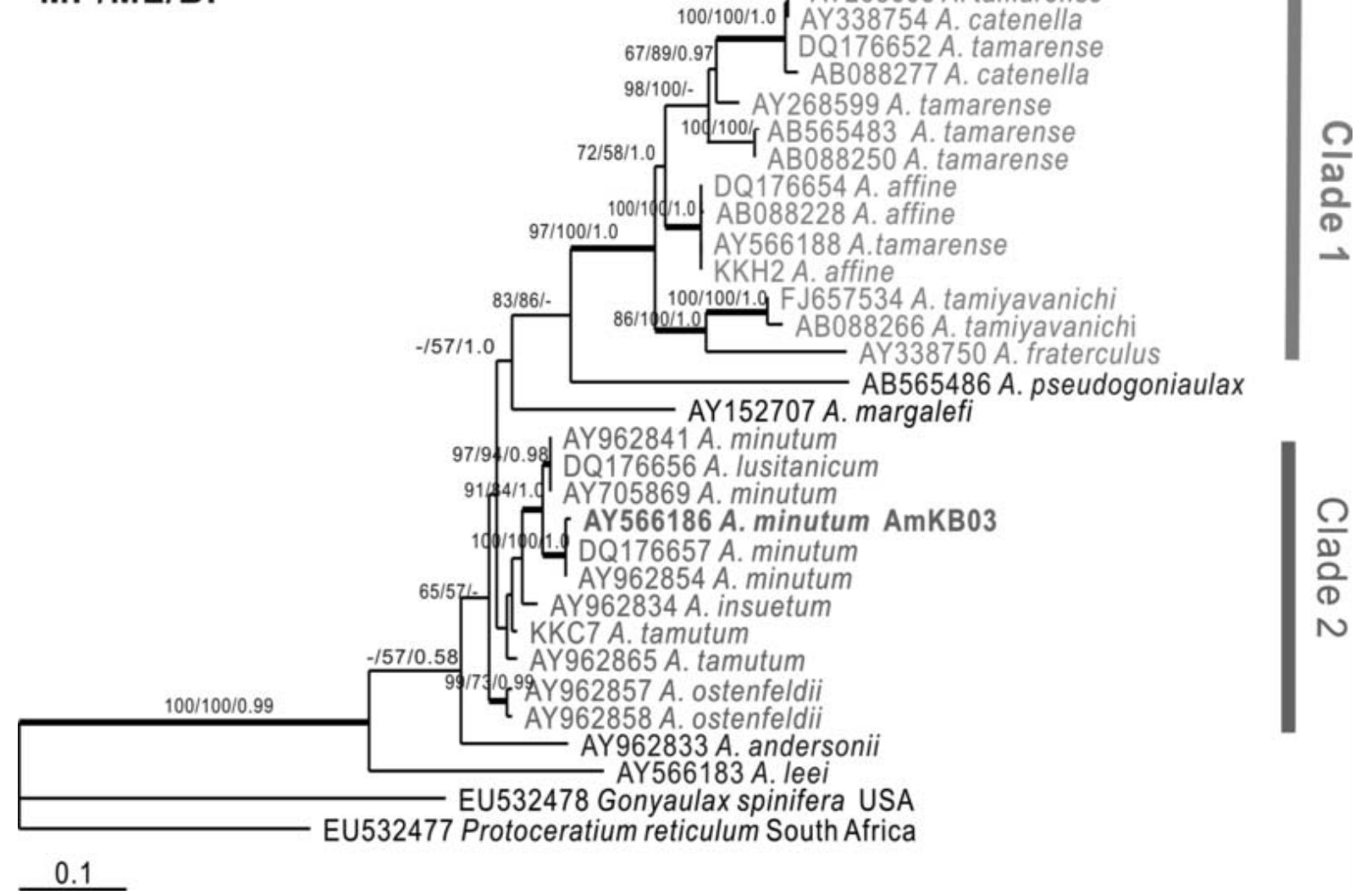

Figure 2. Phylogenetic tree inferred from the sequences of LSU ribosomal RNA gene (D1-D2) of Alexandrium species. Scale bar represents 0.1 evolutionary rates.

\section{MP/ML/BI}

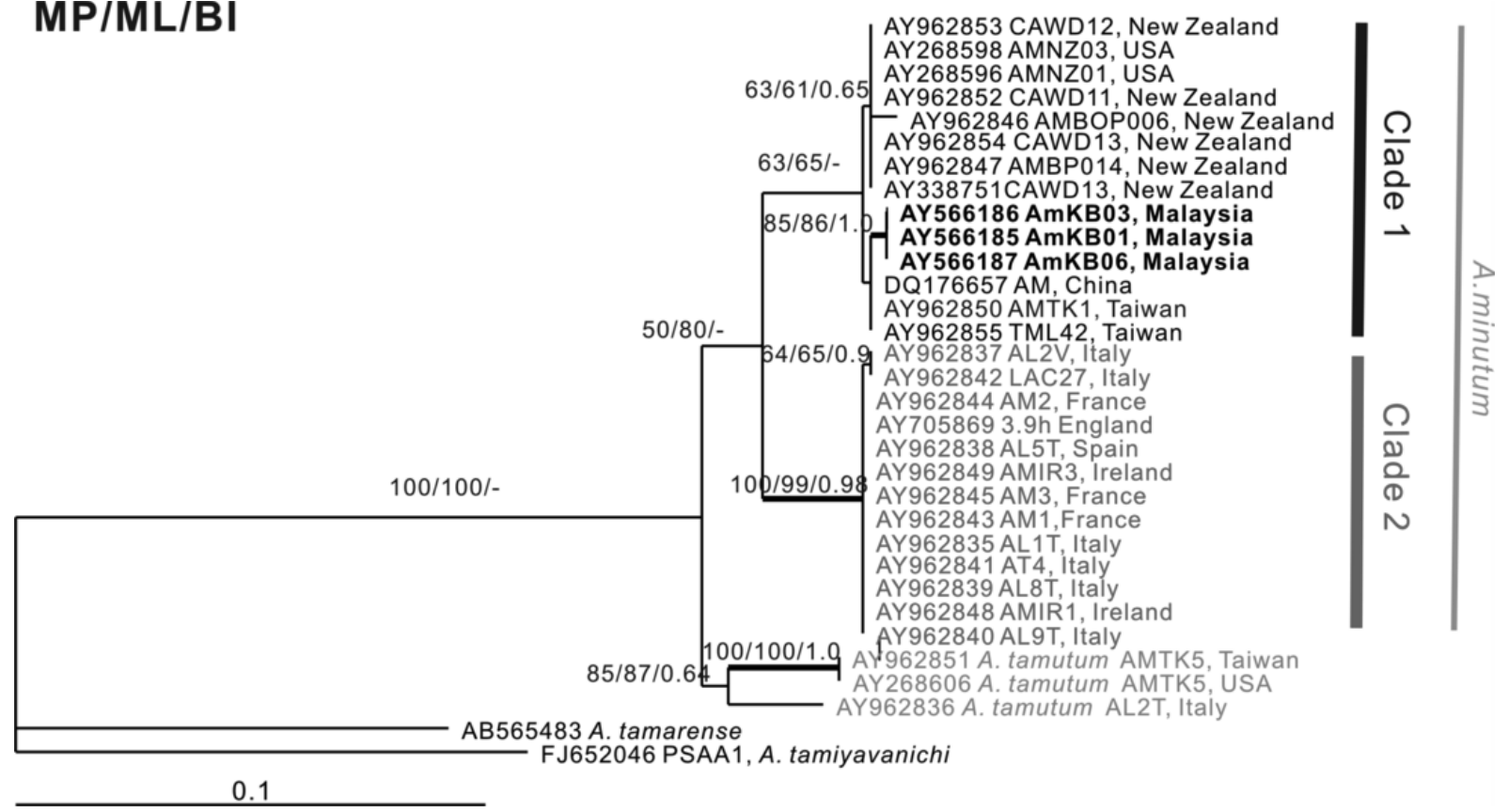

Figure 3. Phylogenetic tree inferred from the sequences of LSU ribosomal RNA gene (D1-D2) of Alexandrium minutum. Scale bar represents 0.1 evolutionary rates. 
Table 1. Potential probe regions of AlexandriumminutumrDNA (D1-D3) based on ARB Probe Design Tool (PDT).

\begin{tabular}{|c|c|c|c|c|c|c|}
\hline NO. & Probe sequence (5'-3') & $\Delta G_{1}^{0}$ & $\Delta \mathbf{G}^{0}{ }_{2}$ & $\Delta \mathbf{G}^{0}{ }_{3}$ & $\Delta \mathbf{G}_{\text {overall }}^{\mathbf{o}}$ & Hybridization Efficiency \\
\hline 1 & AAGAGTCCCTTCCCCGTT & -23.4 & 0.6 & -8.4 & -14.7 & 0.9997 \\
\hline 2 & CTCAAGGAAGAGTCCCTT & -18.2 & -0.3 & -8.1 & -9.4 & 0.4154 \\
\hline 3 & GAAGAGTCCCTTCCCCGT & -23.9 & -0.4 & -6.0 & -17.1 & 1.0000 \\
\hline 4 & CAGTGCTCAAGGAAGAGT & -16.6 & 0.2 & -7.6 & -8.6 & 0.1523 \\
\hline 5 & GCTCAAGGAAGAGTCCCT & -19.9 & -0.3 & -8.1 & -11.2 & 0.9157 \\
\hline 6 & TCCACCAACCACATGCAT & -19.7 & 1.6 & -7.8 & -11.9 & 0.9705 \\
\hline 7 & AGAGTCCCTTCCCCGTTG & -24.2 & 1.3 & -8.4 & -15.6 & 0.9999 \\
\hline 8 & AAGTCCACCAACCACATG & -17.8 & 1.7 & -7.8 & -9.9 & 0.5951 \\
\hline 9 & GAGTCCCTTCCCCGTTGG & -25.3 & 0.6 & -8.4 & -16.7 & 1.0000 \\
\hline 10 & GGAAGAGTCCCTTCCCCG & -23.8 & -2.1 & -6.0 & -15.6 & 0.9999 \\
\hline 11 & TCCCCGTTGGCAAAACAG & -19.0 & -0.1 & -10.1 & -8.4 & 0.1203 \\
\hline 12 & TCAAGGAAGAGTCCCTTC & -17.8 & -0.7 & -8.7 & -8.2 & 0.0901 \\
\hline 13 & AGTGCTCAAGGAAGAGTC & -16.4 & 0.2 & -8.1 & -8.0 & 0.0642 \\
\hline 14 & CCACCAACCACATGCATC & -19.7 & 1.6 & -7.8 & -11.9 & 0.9705 \\
\hline 15 & AGTCCACCAACCACATGC & -20.4 & 1.6 & -7.8 & -12.6 & 0.9897 \\
\hline 16 & AGTCCCTTCCCCGTTGGC & -26.6 & 0.4 & -9.5 & -16.8 & 1.0000 \\
\hline 17 & CCCCGTTGGCAAAACAGC & -20.4 & -0.1 & -9.6 & -10.3 & 0.7212 \\
\hline 18 & CAAGGAAGAGTCCCTTCC & -19.2 & -2.3 & -7.9 & -8.9 & 0.2389 \\
\hline 19 & GTGCTCAAGGAAGAGTCC & -18.3 & -0.1 & -8.1 & -9.7 & 0.5326 \\
\hline 20 & AAGGAAGAGTCCCTTCCC & -20.5 & -2.6 & -6.0 & -11.8 & 0.9690 \\
\hline 21 & TGCTCAAGGAAGAGTCCC & -19.0 & -0.3 & -8.1 & -10.2 & 0.7153 \\
\hline 22 & AGGAAGAGTCCCTTCCCC & -23.2 & -2.6 & -6.0 & -14.6 & 0.9996 \\
\hline 23 & AAATGACAGAGTGGGCAC & -15.4 & 1.0 & -19.5 & 4.1 & $3.6928 \mathrm{e}-10$ \\
\hline 24 & CCGTTGGCAAAACAGCAC & -17.4 & -0.1 & -7.8 & -9.1 & 0.2937 \\
\hline 25 & ACAAAGTCCACCAACCAC & -17.2 & 1.7 & -6.3 & -10.8 & 0.8661 \\
\hline
\end{tabular}

Table 2. Hybridization parameters obtained from ARB for the four potential probe regions.

\begin{tabular}{cccccc}
\hline Probe & $\begin{array}{c}\text { Target sequence } \\
\left(5^{\prime}-3^{\prime}\right)\end{array}$ & $\begin{array}{c}\text { Probe sequence } \\
\left(5^{\prime}-3^{\prime}\right)\end{array}$ & $\begin{array}{c}\text { Length } \\
\text { of probe }\end{array}$ & $\begin{array}{c}\text { G+C } \\
\text { 2AT (melting } \\
\text { temperature) }\end{array}$ \\
\hline 1 & ACGGGGAAGGGACUCUUC & GAAGAGTCCCTTCCCCGT & 18 & 61.1 & 58.0 \\
2 & CCAACGGGGAAGGGACUC & GAGTCCCTTCCCCGTTGG & 18 & 66.7 & 60.0 \\
3 & GCCAACGGGGAAGGGACU & AGTCCCTTCCCCGTTGGC & 18 & 66.7 & 60.0 \\
4 & UGCCAACGGGGAAGGGAC & GTCCCTTCCCCGTTGGCA & 18 & 66.7 & 60.0 \\
\hline
\end{tabular}


A

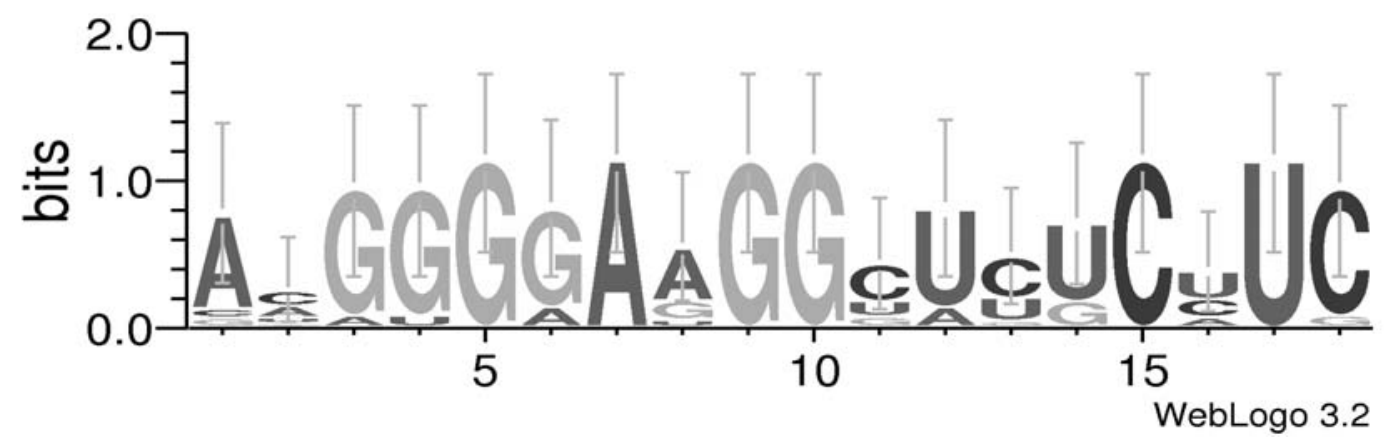

B

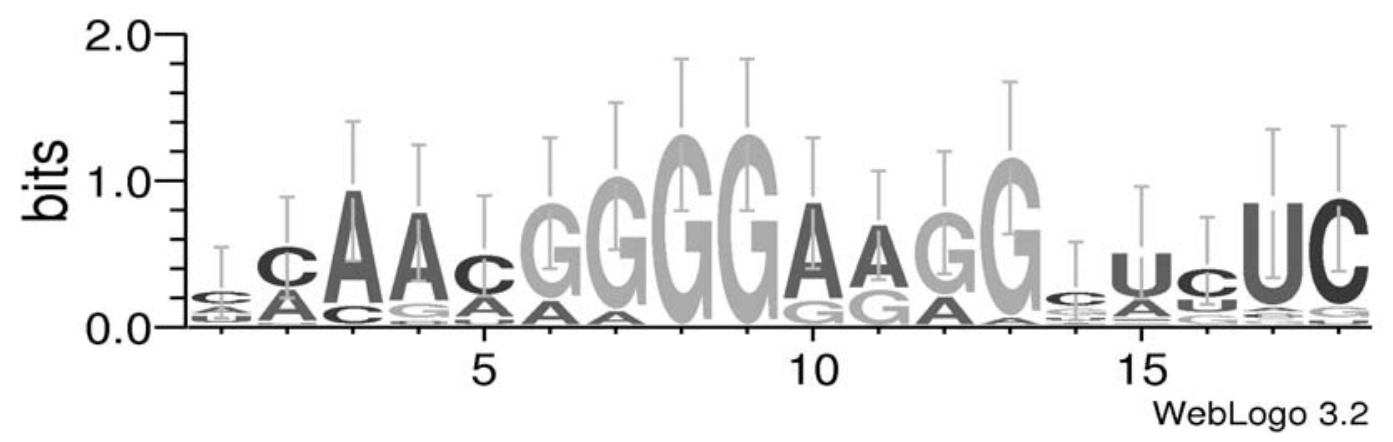

$\mathrm{C}$

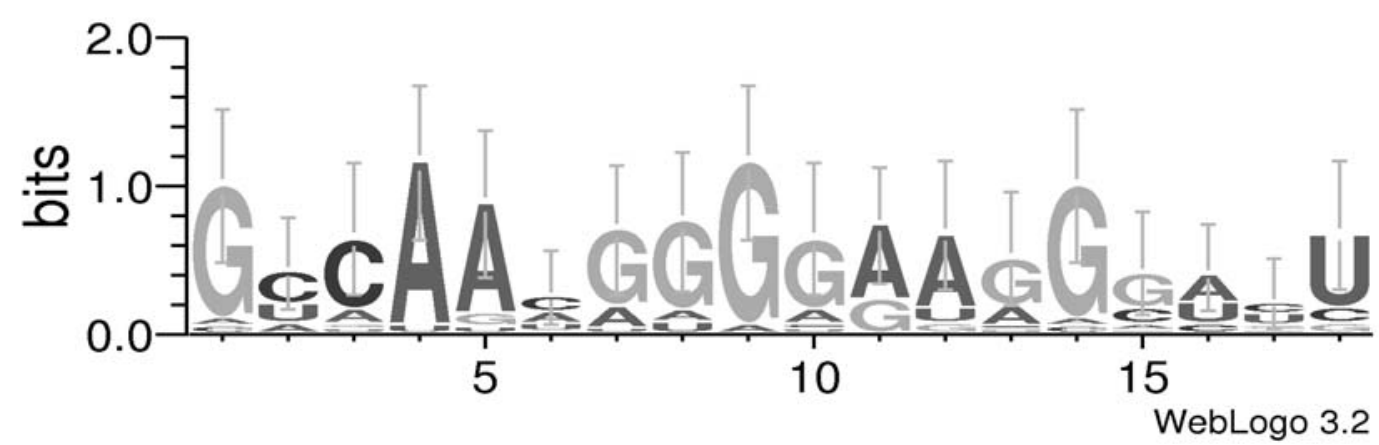

$\mathrm{D}$

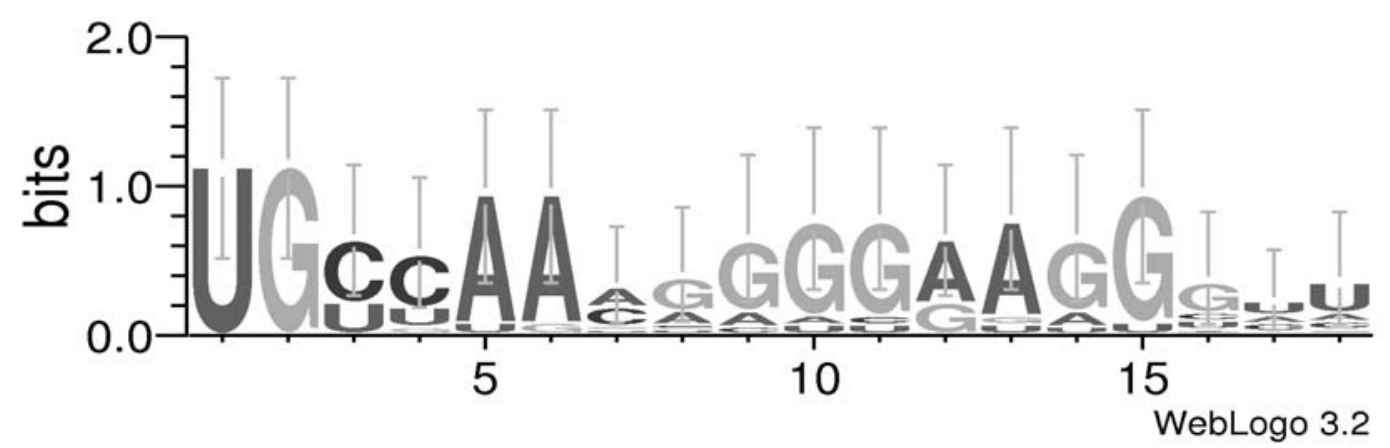

Figure 4. Signature regions of Alexandrium minutum LSU rDNAas potential probe regions. (A) Probe 1, (B) Probe 2, (C) Probe 3, and (D) Probe 4. 
Table 3. Mismatch analysis of probe region (Probe 3: [5'-AGUCCCUUCCCCGUUGGC-3']) against target species (species in Clade 1, Figure 3) and non-target species (species in Clade 2, Figure 3)

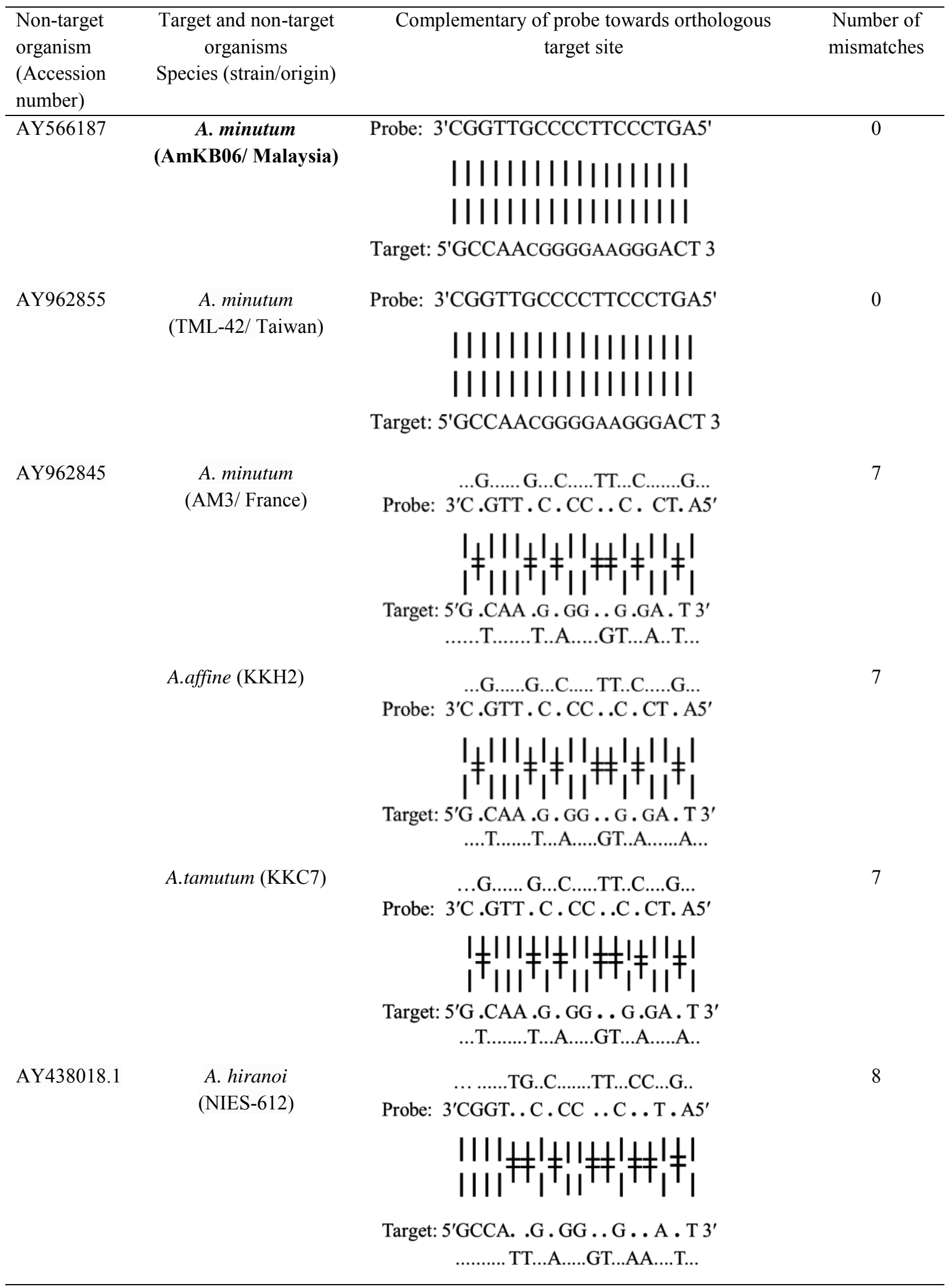




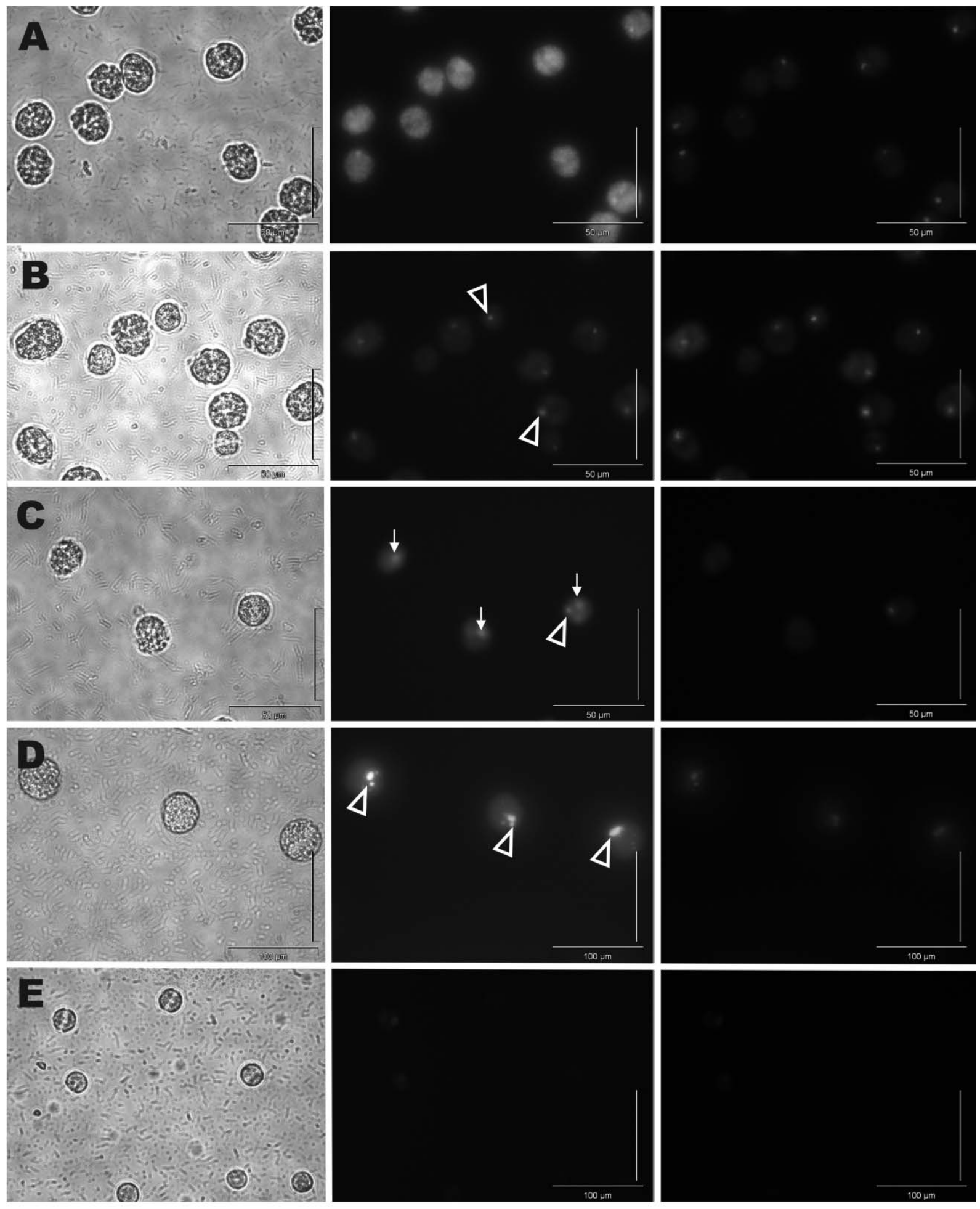

Figure 5. Whole-cell FISH applied on Alexandrium minutum, A. tamiyavanichii and A. tamutum hybridized with uniC positive control (A), uniR negative control (B), species-specific probe towards A. minutum(C), A. tamiyavanichii(D) and A. tamutum(E). Arrows indicate green fluorescent signals from species-specific probe, and arrow heads mark the yellow fluorescent bodies in the cells. Micrographs of these species were taken under bright field (left), blue filter (center) and green filter (right), respectively. 